\title{
Dyadobacter beijingensis sp. nov., isolated from the rhizosphere of turf grasses in China
}

\author{
Correspondence \\ Feiyun Zhang \\ feiyun39@126.com \\ Huili Gong \\ gonghl@263.net
}

\author{
Zhi Dong, ${ }^{1}+$ Xiaoyu Guo, ${ }^{2} \dagger$ Xiaoxia Zhang, ${ }^{3}$ Fubin Oiu, ${ }^{1}$ Lei Sun, ${ }^{4}$ \\ Huili Gong ${ }^{2}$ and Feiyun Zhang ${ }^{1}$ \\ ${ }^{1}$ College of Life Sciences, Capital Normal University, Beijing 100037, People's Republic of
China \\ ${ }^{2}$ Beijing Key Laboratory for Resources Environment and Geography Information System, \\ College of Resources Environment and Tourism, Capital Normal University, Beijing 100037, \\ People's Republic of China \\ ${ }^{3}$ Agricultural Culture Collection Center of China, Institute of Agricultural Resources and \\ Regional Planning, Chinese Academy of Agricultural Sciences, Beijing 100080, \\ People's Republic of China \\ ${ }^{4}$ College of Life Sciences, Hebei University, Baoding 071002, People's Republic of China
}

The genus Dyadobacter was first described by Chelius \& Triplett (2000), and the genus currently comprises three species: Dyadobacter fermentans, isolated from surfacesterilized Zea mays stems (Chelius \& Triplett, 2000), Dyadobacter crusticola, from biological soil crusts (Reddy \& Garcia-Pichel, 2005), and Dyadobacter hamtensis, from the 'snout' of the Hamta glacier (Chaturvedi et al., 2005). Recently, using culture-dependent methods, we examined rhizosphere-associated bacterial communities of the perennial grass Poa pratensis L. irrigated with reclaimed water, a practice which has been in place for more than 4 years. A total of 138 isolates were obtained from Luria-Bertani (LB) medium seeded with a rhizospheric soil sample. Most isolates belonged to the Alphaproteobacteria, Betaproteobacteria, Gammaproteobacteria, Bacteroidetes, Firmicutes and Actinobacteria by $16 \mathrm{~S}$ rRNA gene sequencing (X. Guo and $Z$. Dong, unpublished results). In the present study, one of the isolates, designated $\mathrm{A} 54^{\mathrm{T}}$, was assigned to the genus Dyadobacter on the basis of phenotypic, chemotaxonomic and phylogenetic analyses.

TThese authors contributed equally to this work.

The GenBank/EMBL/DDBJ accession number for the 16S rRNA gene sequence of strain $A 54^{\top}$ is DO335125.
Strain $\mathrm{A} 54^{\mathrm{T}}$ and D. fermentans ATCC $700827^{\mathrm{T}}$, as a reference strain, were cultivated on LB medium or R2A medium at $28{ }^{\circ} \mathrm{C}$ and maintained in $\mathrm{R} 2 \mathrm{~A}$ medium at $4{ }^{\circ} \mathrm{C}$ or as a glycerol suspension $(20 \%, \mathrm{v} / \mathrm{v})$ at $-20{ }^{\circ} \mathrm{C}$.

R2A was used for determination of growth of strain $\mathrm{A} 54^{\mathrm{T}}$ at various temperatures, at different $\mathrm{pH}$ values and in the presence of various concentrations of $\mathrm{NaCl}$. Phenotypic characteristics such as colony morphology, cell morphology, various enzyme activities (Hugh \& Leifson, 1953), growth in various media such as YM (Beringer, 1974), R2A and peptone water (Chelius \& Triplett, 2000) and sensitivity to antibiotics at $28{ }^{\circ} \mathrm{C}$ were ascertained by using standard methods (Lanyi, 1987; Smibert \& Krieg, 1994). API 50CH (bioMérieux) was employed to test carbon assimilation according to the manufacturer's instructions. The catalase test was done with cells scraped from R2A and treated with $3 \%(\mathrm{w} / \mathrm{v})$ hydrogen peroxide. The presence of flexirubinlike pigments was tested by measuring the absorbance spectrum of absolute ethanol and alkaline-ethanol extracts of lysed cells (Weeks, 1981). Fatty acid analysis was performed using standard methods and compared to the database of fatty acids in the MIDI Sherlock Microbial Identification System (Microbial ID). Genomic DNA was extracted and purified from cells using the procedure of 
Marmur \& Doty (1962). DNA base compositions were determined using the thermal melting protocol (De Ley, 1970) with Escherichia coli K-12 as a reference strain. Levels of DNA relatedness were estimated by measurement of the initial reassociation rate (De Ley et al., 1970).

The 16S rRNA gene was amplified by PCR using universal primers $27 \mathrm{f}$ and 1492r (Lane, 1991). The amplified 16S rRNA gene fragment was purified from agarose gels by using a Tiangen kit and cloned into the pGEM-T Easy vector (Promega) according to the technical manual. Sequence

Table 1. Phenotypic characteristics that differentiate strain $\mathrm{A} 54^{\top}, D$. fermentans, D. crusticola and D. hamtensis

Strains: 1, strain $\mathrm{A} 54^{\mathrm{T}}$ (D. beijingensis sp. nov.); 2, D. fermentans NS- $114^{\mathrm{T}}$; 3, D. crusticola CP183-8 $-8^{\mathrm{T}}$ 4, D. hamtensis HHS $11^{\mathrm{T}}$. +, Positive; -, negative; W, weak reaction; NA, data not available. Data for $\mathrm{A} 54^{\mathrm{T}}$ and $D$. fermentans NS$-114^{\mathrm{T}}$ were obtained in the present study; data for D. crusticola CP183-8 ${ }^{\mathrm{T}}$ and D. hamtensis HHS $11^{\mathrm{T}}$ were taken from Chaturvedi et al. (2005).

\begin{tabular}{|c|c|c|c|c|}
\hline Characteristic & 1 & 2 & 3 & 4 \\
\hline \multicolumn{5}{|l|}{ Growth at: } \\
\hline $5^{\circ} \mathrm{C}$ & + & - & + & - \\
\hline $37^{\circ} \mathrm{C}$ & - & + & - & + \\
\hline Growth on peptone water & + & + & NA & + \\
\hline \multicolumn{5}{|l|}{ Acid from: } \\
\hline Sucrose & + & + & - & - \\
\hline D-Glucose & + & + & - & + \\
\hline D-Fructose & + & - & + & - \\
\hline \multicolumn{5}{|l|}{ Carbon-source utilization } \\
\hline D-Arabinose & - & + & - & + \\
\hline D-Mannitol & - & + & - & - \\
\hline Dulcitol & + & $\mathrm{w}$ & + & - \\
\hline myo-Inositol & + & + & + & - \\
\hline Sodium acetate & - & + & - & + \\
\hline Tartrate & - & + & - & + \\
\hline L-Rhamnose & - & + & - & - \\
\hline Inositol & + & + & + & - \\
\hline D-Mannitol & + & $\mathrm{W}$ & $-1+$ & - \\
\hline D-Sorbitol & - & + & + & - \\
\hline \multicolumn{5}{|c|}{ Antibiotic resistance $(\mu \mathrm{g} \text { per disc })^{*}$} \\
\hline Ampicillin (25) & + & + & + & - \\
\hline Rifampicin $(25) \dagger$ & - & - & + & + \\
\hline Streptomycin $(10)$ & + & + & + & - \\
\hline Gentamicin (10) & - & + & - & + \\
\hline Erythromycin (10) & - & + & + & + \\
\hline Roxithromycin (30) & - & + & + & - \\
\hline Vancomycin $(30)$ & + & - & + & + \\
\hline DNA G $+\mathrm{C}$ content $(\mathrm{mol} \%)$ & 49.2 & 48 & 48 & 49 \\
\hline
\end{tabular}

*The amounts of antibiotic used by Chaturvedi et al. (2005) to generate these results are not necessarily the same as the amounts used in this study.

$\dagger$ Rifampicin was tested at $25 \mu \mathrm{g} \mathrm{ml}^{-1}$ in this study. data were obtained by single-pass double-stranded analysis using primers T7 and SP6, which flank the cloning region in the pGEM-T Easy vector. The sequence of $\mathrm{A} 54^{\mathrm{T}}$ was aligned with those of closely related species of Dyadobacter and members of other related genera using CLUSTAL X version 1.8 (Thompson et al., 1997) and phylogenetic affiliations were inferred using TREECON (version 1.3b) and the PHYLIP package. The Kimura two-parameter method was used for distance calculations (Kimura, 1980) and the resultant tree topologies were evaluated by bootstrap analyses (Felsenstein, 1985) based on 1000 resamplings.

Morphological, physiological, biochemical and chemotaxonomic characteristics of strain $\mathrm{A} 54^{\mathrm{T}}$ are given in the species description below and in Table 1. Strain $\mathrm{A} 54^{\mathrm{T}}$ is Gramnegative, aerobic, oxidase- and catalase-positive and ferments glucose but not sucrose and cells are non-motile, rodshaped in both exponential and stationary phases and appear in pairs. The DNA G $+\mathrm{C}$ content of strain $\mathrm{A} 54^{\mathrm{T}}$ was $49.2 \mathrm{~mol} \%$, which is in the range for known Dyadobacter species (Table 1).

In addition, strain $\mathrm{A} 54^{\mathrm{T}}$ produces a flexirubin-like yellow pigment, a characteristic feature of the genus Dyadobacter. The strain exhibited the three peaks characteristic of flexirubin at 428, 452 and $478 \mathrm{~nm}$ in ethanol (Fig. 1) (Chelius \& Triplett, 2000; Chaturvedi et al., 2005; Reddy \& GarciaPichel, 2005). The addition of alkali $(20 \% \mathrm{KOH})$ changed the colour of the pigment to orange and broadened the peak, thus confirming that it is a flexirubin-type pigment (Weeks, 1981). Strain $\mathrm{A} 54^{\mathrm{T}}$ contained the following major fatty acids: iso- $\mathrm{C}_{15: 0}(19.22 \%), \mathrm{C}_{16: 1} \omega 7 c(17.46 \%)$, iso- $\mathrm{C}_{15: 0} 2$ $\mathrm{OH}(23.38 \%), \mathrm{C}_{16: 1} \omega 5 c(10.26 \%), \mathrm{C}_{16: 0} 3-\mathrm{OH}(3.09 \%)$ and iso- $\mathrm{C}_{17: 0} 3-\mathrm{OH}(12.41 \%)$. In D. fermentans NS114, these fatty acids were also present; however, the level of iso$\mathrm{C}_{17: 0} 3-\mathrm{OH}$ was lower, while $\mathrm{C}_{16: 1} \omega 5 c$ and $\mathrm{C}_{16: 1} \omega 7 c$ were more abundant [although for D. fermentans $\mathrm{NS}_{11} 4^{\mathrm{T}}$, Chelius \& Triplett (2000) reported $\mathrm{C}_{16: 1} \omega 7 c$ as summed feature 3, which may also contain iso- $\mathrm{C}_{15: 0} 2-\mathrm{OH}$ ( Table 2).

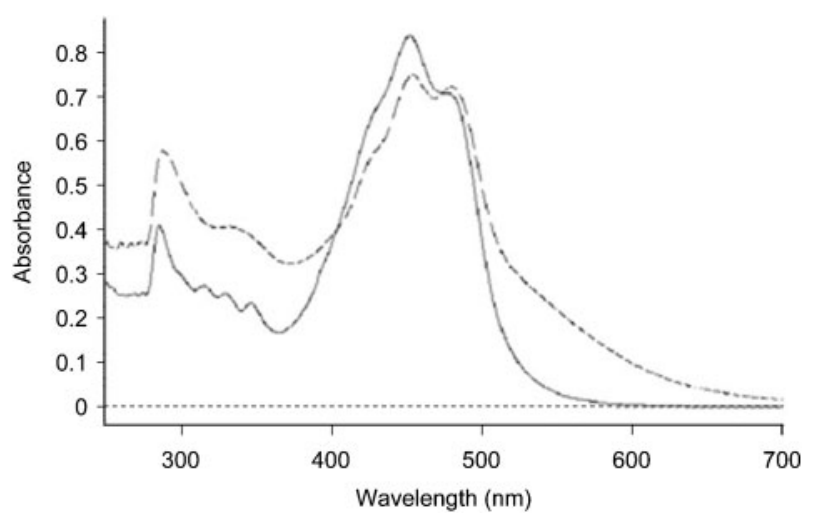

Fig. 1. Absorbance spectrum of ethanol (solid line) and alkaline ethanol (dashed line) extracts of strain $A 54^{\top}$. 
Table 2. Fatty acid compositions (\%) of strain $A 54^{\top}, D$. fermentans, $D$. crusticola and $D$. hamtensis

Strains: $1, \mathrm{~A}_{5} 4^{\mathrm{T}}$ (D. beijingensis sp. nov.); 2, D. fermentans NS$114^{\mathrm{T}}$ (data from Chelius \& Triplett, 2000); 3, D. crusticola CP183$8^{\mathrm{T}}$ (Reddy \& Garcia-Pichel, 2005); 4, D. hamtensis HHS $11^{\mathrm{T}}$ (Chaturvedi et al., 2005). Strain $\mathrm{A} 54^{\mathrm{T}}$ was grown in R2A medium at $28^{\circ} \mathrm{C}$ for determination of the fatty acid composition. -, Fatty acid not reported; NA, not applicable (see footnote).

\begin{tabular}{|c|c|c|c|c|}
\hline Fatty acid & 1 & 2 & 3 & 4 \\
\hline $\mathrm{C}_{14: 0}$ & 0.57 & - & 1.4 & 1.23 \\
\hline iso- $\mathrm{C}_{15: 1}$ & 0.50 & - & 1.5 & 3.7 \\
\hline iso- $\mathrm{C}_{15: 0}$ & 19.22 & 16.8 & 13.4 & 26.49 \\
\hline anteiso- $\mathrm{C}_{15: 0}$ & 1.04 & - & - & - \\
\hline $\mathrm{C}_{16: 1} \omega 5 c$ & 10.26 & 17.5 & 21.4 & 19.75 \\
\hline $\mathrm{C}_{16: 1} \omega 7 c$ & 17.46 & $43.5^{*}$ & 41.2 & 14.81 \\
\hline $\mathrm{C}_{16: 0}$ & 2.91 & 4.76 & 12.4 & 8.64 \\
\hline iso- $\mathrm{C}_{15: 0} 2-\mathrm{OH}$ & 23.38 & NA & - & - \\
\hline iso- $\mathrm{C}_{15: 0} 3-\mathrm{OH}$ & 2.63 & 2.74 & 2.4 & - \\
\hline Unknown ECL 13.57 & 2.11 & 1.32 & 0.3 & - \\
\hline $\mathrm{C}_{16: 0} 3-\mathrm{OH}$ & 3.09 & 4.66 & 2.2 & 2.46 \\
\hline iso- $\mathrm{C}_{17: 0} 3-\mathrm{OH}$ & 12.41 & 7.38 & 2.9 & 22.22 \\
\hline
\end{tabular}

${ }^{\star}$ Reported as summed feature 3, which contains $\mathrm{C}_{16: 1} \omega 7 \mathrm{c}$ and/or iso- $\mathrm{C}_{15: 0}$ 2-OH.

The placement of strain $\mathrm{A} 54^{\mathrm{T}}$ within the genus Dyadobacter is further supported by phylogenetic analysis (Fig. 2) based on the 16S rRNA gene sequence. It forms a robust clade with the type strains of species of the genus Dyadobacter. The nearly complete $16 \mathrm{~S}$ rRNA gene sequence of strain $\mathrm{A} 54^{\mathrm{T}}(1411 \mathrm{bp})$ showed $97.7,94.4$ and $94.7 \%$ similarity, respectively, to those of D. fermentans $\mathrm{NS}_{11}{ }^{\mathrm{T}}$, D. hamtensis HHS $11^{\mathrm{T}}$ and D. crusticola DSM $16708^{\mathrm{T}}$. The results of DNA-DNA hybridization did not show significant relatedness ( $<25 \%$ hybridization) between strain $\mathrm{A} 54^{\mathrm{T}}$ and $D$. fermentans ATCC $700827^{\mathrm{T}}$, indicating that strain $\mathrm{A} 54^{\mathrm{T}}$ is different from D. fermentans ATCC $700827^{\mathrm{T}}$ at the species level when the recommendation of a threshold value of $70 \%$ DNA-DNA relatedness for definition of bacterial species is considered (Wayne et al., 1987).

Therefore, on the basis of morphological, physiological, biochemical, chemotaxonomic and phylogenetic data, isolate $\mathrm{A} 54^{\mathrm{T}}$ should be classified as representing a novel species, for which we propose the name Dyadobacter beijingensis sp. nov.

\section{Description of Dyadobacter beijingensis sp. nov.}

Dyadobacter beijingensis (bei.jing.en'sis. N.L. masc. adj. beijingensis pertaining to Beijing, the geographical origin of the type strain).

Colonies on R2A agar are yellow, mucoid, flaky, convex and smooth. Cells are aerobic, non-motile, Gram-negative rods. Growth occurs at $4-35^{\circ} \mathrm{C}$ (optimum $28^{\circ} \mathrm{C}$ ) but not at $37^{\circ} \mathrm{C}$, at $\mathrm{pH}$ 6-8 (optimum $\mathrm{pH} 7$ ) and in the presence of up to $1.5 \% \mathrm{NaCl}$. Growth occurs in peptone water, on LB medium and R2A medium. Positive for catalase and oxidase and negative for urease, gelatinase, hydrolysis of casein, cellulose, starch and gelatin, $\mathrm{H}_{2} \mathrm{~S}$ production, the methyl red, indole and Voges-Proskauer tests and reduction of nitrate to nitrite. Acid is produced from sucrose, D-glucose and D-fructose, but not from D-arabinose, D-galactose or D-rhamnose. Utilizes erythritol, L-arabinose, D- and Lxylose, D-adonitol, methyl $\beta$-D-xylopyranoside, D-galactose, D-glucose, D-fructose, D-mannose, dulcitol, inositol,

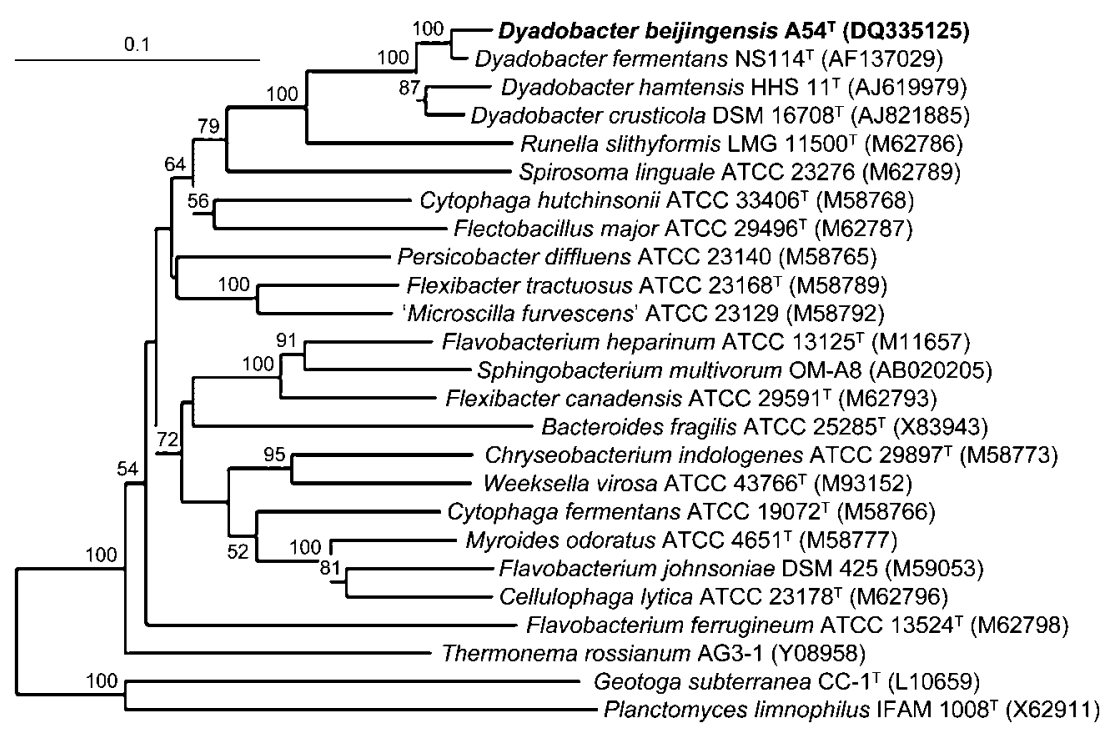

Fig. 2. Neighbour-joining tree showing the phylogenetic position of strain $A 54^{\top}$ and representatives of related taxa, based on $16 \mathrm{~S}$ rRNA gene sequences. Bootstrap values (expressed as percentages of 1000 resamplings) $>50 \%$ are shown at branch points. Bar, 0.1 substitutions per nucleotide position. 
D-mannitol, methyl $\alpha$-D-mannopyranoside, methyl $\alpha$-Dglucopyranoside, arbutin, aesculin, citrate, salicin, D-cellobiose, D-maltose, D-lactose, D-melibiose, sucrose, D-trehalose, inulin, D-melezitose, D-raffinose, gentiobiose and D-fucose as sole carbon sources. Does not utilize glycerol, D-arabinose, D-mannitol, D-ribose, lactic acid, myo-inositol, sodium acetate, tartrate, L-rhamnose, L-sorbose, D-sorbitol, $\mathrm{N}$-acetylglucosamine, amygdalin, xylitol, D-turanose, Dlyxose, L-fucose, D-arabitol, L-arabitol, glycogen, D-tagatose, starch, potassium gluconate, potassium 2-ketogluconate, potassium 5-ketogluconate or methanol as sole carbon sources. Cells are sensitive to ( $\mu$ g per disc) acetylspiramycin (100), amoxicillin (30), ampicillin (25), carbenicillin (100), cephalothin (30), chloramphenicol (25), erythromycin (10), gentamicin (10), kanamycin (50), lincomycin (20), norfloxacin (10), penicillin (10), roxithromycin (30), spectinomycin (10) and streptomycin (10), but resistant to levofloxacin (100), rifampicin (25), tetracycline (10) and vancomycin (30). The pigment present is of the flexirubin type, with absorption maxima at 428,452 and $478 \mathrm{~nm}$. The $\mathrm{G}+\mathrm{C}$ content of the DNA is $49.2 \mathrm{~mol} \%$. The major cellular fatty acids are $15: 0$ iso, $16: 1 \omega 7 c, 15: 0$ iso $2-\mathrm{OH}, 16: 1 \omega 5 c$, 16:0 3-OH and 17:0 iso $3-\mathrm{OH}$.

The type strain, A54 ${ }^{\mathrm{T}}$ ( = CGMCC $1.6375^{\mathrm{T}}=\mathrm{JCM} 14200^{\mathrm{T}}$ ), was isolated from the rhizosphere of turf grasses.

\section{Acknowledgements}

This work was supported by the National Natural Science Foundation of China (no. 30571010, no. 40571125) and the Beijing Municipal Commission of Education (KE200410028014).

\section{References}

Beringer, J. E. (1974). R-factor transfer in Rhizobium leguminosarum. J Gen Microbiol 84, 188-198.

Chaturvedi, P., Reddy, G. S. N. \& Shivaji, S. (2005). Dyadobacter hamtensis sp. nov., from Hamta glacier, located in the Himalayas, India. Int J Syst Evol Microbiol 55, 2113-2117.

Chelius, M. K. \& Triplett, W. E. (2000). Dyadobacter fermentans gen. nov., sp. nov., a novel Gram-negative bacterium isolated from surface-sterilized Zea mays stems. Int J Syst Evol Microbiol 50, $751-758$
De Ley, J. (1970). Reexamination of the association between melting point, buoyant density, and chemical base composition of deoxyribonucleic acid. J Bacteriol 101, 738-754.

De Ley, J., Cattoir, H. \& Reynaerts, A. (1970). The quantitative measurement of DNA hybridization from renaturation rates. Eur J Biochem 12, 133-142.

Felsenstein, J. (1985). Confidence limits on phylogenies: an approach using the bootstrap. Evolution 39, 783-791.

Hugh, R. \& Leifson, E. (1953). The taxonomic significance of fermentative versus oxidative metabolism of carbohydrates by various gram negative bacteria. J Bacteriol 66, 24-26.

Kimura, M. (1980). A simple method for estimating evolutionary rates of base substitutions through comparative studies of nucleotide sequences. J Mol Evol 16, 111-120.

Lane, D. L. (1991). 16S/23S rRNA sequencing. In Nucleic Acid Techniques in Bacterial Systematics, pp. 115-175. Edited by E. Stackebrandt \& M. Goodfellow. New York: Wiley.

Lanyi, B. (1987). Classical and rapid identification methods for medically important bacteria. Methods Microbiol 19, 1-67.

Marmur, J. \& Doty, P. (1962). Determination of the base composition of deoxyribonucleic acid from its thermal denaturation temperature. J Mol Biol 5, 109-118.

Reddy, G. S. N. \& Garcia-Pichel, F. (2005). Dyadobacter crusticola sp. nov., from biological soil crusts in the Colorado Plateau, USA, and an emended description of the genus Dyadobacter Chelius and Triplett 2000. Int J Syst Evol Microbiol 55, 1295-1299.

Smibert, R. M. \& Krieg, N. R. (1994). Phenotypic characterization. In Methods for General and Molecular Bacteriology, pp. 607-654. Edited by P. Gerhardt. Washington, DC: American Society for Microbiology.

Thompson, J. D., Gibson, T. J., Plewniak, F., Jeanmougin, F. \& Higgins, D. G. (1997). The CLUSTAL_X windows interface: flexible strategies for multiple sequence alignment aided by quality analysis tools. Nucleic Acids Res 25, 4876-4882.

Wayne, L. G., Brenner, D. J., Colwell, R. R., Grimont, P. A. D., Kandler, O., Krichevsky, M. I., Moore, L. H., Moore, W. E. C., Murray, R. G. E. \& other authors (1987). International Committee on Systematic Bacteriology. Report of the ad hoc committee on reconciliation of approaches to bacterial systematics. Int $J$ Syst Bacteriol 37, 463-464.

Weeks, O. B. (1981). Preliminary studies of the pigments of Flavobacterium breve NCTC 11099 and Flavobacterium odoratum NCTC 11036. In The Flavobacterium-Cytophaga Group, pp. 108-114. Edited by H. Reichenbach \& O. B. Weeks. Weinheim: Gesellschaft für Biotechnologische Forschung. 